\title{
An Empirical Study on Economic Growth and Carbon Emissions of G20 Group
}

\author{
Huayong Niu \\ International Business School \\ Beijing Foreign Studies University \\ Beijing, China \\ niuhuayong@bfsu.edu.cn
}

\author{
Han $\mathrm{Li}^{*}$ \\ International Business School \\ Beijing Foreign Studies University \\ Beijing, China \\ lihan@bfsu.edu.cn \\ *Corresponding author
}

\begin{abstract}
The aim of the paper is to explore the relationship between economic growth and carbon dioxide emissions for a small sample of open and industrialized countries. We analyze panel data of the 19 nations of the G20 from 1995 to 2010 . The research finds no compelling evidence for the existence of Environmental Kuznets Curve. Further research is needed.
\end{abstract}

\section{Keywords-economic growth; carbon emissions; Environmental Kuznets Curve; Pollution Haven}

\section{INTRODUCTION}

The threat of climate change has attracted great attention in recent years. One of the most important issues is how to reduce carbon emissions, since $\mathrm{CO} 2$ is considered to be the main driving force behind global warming. However, $\mathrm{CO} 2$ emissions are still increasing despite common efforts to implement international binding agreements, such as the Kyoto Protocol. The objective of this paper is to examine the empirical relationship between carbon emissions and economic growth, investigate what are the main determinants of carbon emissions and how openness affects it.

The rest of the paper is organized as follows. Section 2 analyzes the theoretical links and empirical evidence between economic growth, carbon emissions and other factors. Section 3 introduces the model, data and estimation method. Section 4 presents the estimation results and Section 5 concludes.

\section{ANALYSIS OF THE THEORETICAL LINKS}

\section{A. Economic Growth and $\mathrm{CO}_{2}$ Emissions}

Existing research on the relationship between environmental quality and economic growth mainly focuses on Environmental Kuznets Curve (EKC) approach. According to the EKC hypothesis, the relationship between per capita GDP and per capita pollutant emissions has an inverted-U shape. This implies that, past a certain point, economic growth may actually be beneficial to environmental quality.

Theoretical and empirical studies in general agree on the existence of the inverted- $U$ form relationship between income level and some local pollution indicators such as wastewater discharge and suspended particles. However, the question of the existence of the EKC for the global pollution case of carbon dioxide has not yet been fully resolved ( $\mathrm{He}$ and Richard, 2010). From a theoretical point of view, the original inverted-U relationship is less likely for $\mathrm{CO}_{2}$ emissions since these emissions cause problems on a global scale, and the social costs of global warming accrue both across time and nations. Therefore the incentive for freeriding is much stronger and the positive correlation between income and $\mathrm{CO}_{2}$ emissions tends to persist even for very high income levels (Arrow et al., 1995).

In line with this argument, the relationships between $\mathrm{CO}_{2}$ emissions and economic growth can be divided into: (i) linear, a monotonically increasing relationship between $\mathrm{CO}_{2}$ and income (ii) inverted U-shaped, implies that GDP is both the cause and cure of the environmental problem (Galeotti and Lanza, 2005). (iii) $\mathrm{N}$-shaped, implies that any diminishing of pollution is only temporary, economic growth cannot be the solution to such environmental problems.

The evidence for environmental Kuznets curve hypothesis for $\mathrm{CO}_{2}$ is "at best mixed" (Galeotti et al., 2006). One potential reason is carbon dioxide causes problem in global scale in terms of its wide spread and longevity in the atmosphere, whilst the other "more local" pollutants have more clear EKC. Also the use of control variables has great influence.

\section{B. International Trade and CO2 Emissions}

In open economies, besides that domestic economic growth may raise $\mathrm{CO}_{2}$ emission levels, international trade may have a significant influence on carbon emissions. It may alter the composition of output because of the differences in the stringency of the pollution regulations in different countries (Pollution Haven Hypothesis) (Taylor, 2005). Theoretically, carbon emissions might rise in the lax regulation country and fall in the tight regulation country.

The pollution haven hypothesis $(\mathrm{PHH})$ predicts that, under free trade, pollution-intensive production will move from developed countries to developing countries. Developing countries lower their environmental standard to 
attract foreign investment, while multinational firms take advantage of the lax environmental regulation moving the heavy polluted factories from their own countries to avoid paying high level pollution abatement costs (developed countries have more stringent environmental standard). Over time, developing countries will develop a comparative advantage in pollution-intensive industries and become "havens" for the world's polluting industries (Temurshoev, 2006).

However, there is no consensus in the economic literature on whether or not there is a pollution haven effect. Both general and partial equilibrium approaches have shown that such an effect is possible, but the empirical research provides conflicting evidence regarding the effect of trade on environmental quality (Jayadevappa and Chhatre, 2000).

\section{MODEL, DATA AND METHOD}

\section{A. Model}

This study examines the relationship between GDP and $\mathrm{CO}_{2}$ emissions. We start with the basic empirical specification and include some control variables in order to account for the different stages of economic development, regional disparity and other structural differences. Since the independent variables do not have an immediate influence on carbon emissions. The level of emissions depend on the existing technologies and the existing structure of industrial output, which can only slowly change, therefore we employ a one-year lag for all independent variables (same as Iwata et al, 2012). The lagged independent variables also help to control for the possible endogeneity of these variables if their current value was employed.

Then the final functional form is below:

$$
\begin{aligned}
\mathrm{CO}_{2 \mathrm{it}}=\alpha+\beta_{1} \mathrm{GDP}_{\mathrm{it}-1}+\beta_{2} \mathrm{GDP}_{\mathrm{it}-1}^{2}+\beta_{3} \mathrm{GDP}_{\mathrm{it}-1}^{3} \\
+\beta_{4} \mathrm{IMP}_{\mathrm{it}-1}+\beta_{5} \mathrm{EXP}_{\mathrm{it}-1}+\beta_{6} \mathrm{IND}_{\mathrm{it}-1} \\
+\beta_{7} \mathrm{FDI}_{\mathrm{it}-1}+\beta_{8} \mathrm{CPI}_{\mathrm{it}-1}+\eta_{\mathrm{i}}+\gamma_{\mathrm{t}}+\epsilon_{\mathrm{it}}
\end{aligned}
$$

The subscripts $\mathrm{i}$ and $\mathrm{t}$ denote countries and years respectively, the variables $\mathrm{CO} 2_{\text {it }}$ and $\mathrm{GDP}_{\text {it }}$ denote carbon emission and economic growth, IMP ${ }_{i t}$ and EXP $_{i t}$ denote imports and exports as a share of GDP separately, IND it $_{\text {it }}$ denotes the share of industrial sector, FDI $_{\text {it }}$ denotes net inflows of foreign direct investment as a share of GDP and $\mathrm{CPI}_{\mathrm{it}}$ is short for Corruption Perceptions Index denotes the stringency of the environmental standard. The error term $\varepsilon_{i t}$ is composed of three elements, $\eta_{i}$ stands for time-invariant regional effects, $\gamma_{t}$ denotes the location-invariant time effects, and other deviation of the observed value from the true value (which is assumed to be randomly distributed with a mean of 0 and a constant variance).

\section{B. Data Descriptions}

Our sample comprises of 19 countries from G20 with a 16 years time length from 1995 to 2010 . The G20 is a group of heads of government or state from 20 leading economies,
19 countries ${ }^{1}$ plus the European Union. Collectively, G20 members represent $90 \%$ of the global GDP, $80 \%$ of the global-trade, over $2 / 3$ of the world population, and $84 \%$ of the anthropogenic carbon emissions. The European Union is excluded from this analysis. Details of the data are in the table below.

In order to account for the different stages of economic development, position relative to the technological frontier and other structural differences, we classify the sample into two groups according to the World Bank's World Development Indicators ${ }^{2}$.

- High-income economies (\$12,616 or more) - eleven

Australia, Canada, France, Germany, Italy, Japan, South Korea, Russia, Saudi Arabia, United Kingdom, United States

- $\quad$ Middle-income economies (\$1,036 to \$12,615) - eight

Argentina, Brazil, China, India, Indonesia, Mexico, South Africa, Turkey

TABLE I. DATA INFORMATION

\begin{tabular}{|c|l|c|c|}
\hline Variables & \multicolumn{1}{|c|}{ Definition } & Dimension & Source \\
\hline $\mathrm{CO}_{2}$ & $\mathrm{CO}_{2}$ emissions per capita & $\begin{array}{c}\text { tonnes } \\
\mathrm{CO} 2 / \\
\text { capita }\end{array}$ & $\begin{array}{c}\text { International } \\
\text { Energy } \\
\text { Agency }\end{array}$ \\
\hline gdp & $\begin{array}{l}\text { GDP per capita based on } \\
\text { purchasing power parity } \\
\text { and converted to } \\
\text { international dollars }\end{array}$ & $\begin{array}{c}\text { constant } \\
2005 \\
\text { internatio } \\
\text { nal \$ }\end{array}$ & World Bank \\
\hline imp & Imports as a share of GDP & $\%$ of GDP & World Bank \\
\hline exp & Exports as a share of GDP & $\%$ of GDP & World Bank \\
\hline ind & $\begin{array}{l}\text { Industry sector value } \\
\text { added divided by GDP }\end{array}$ & $\%$ of GDP & World Bank \\
\hline fdi & $\begin{array}{l}\text { Foreign direct investment } \\
\text { net inflows divided by } \\
\text { GDP }\end{array}$ & $\begin{array}{l}\% \text { of GDP } \\
\text { Index }\end{array}$ & World Bank \\
\hline cpi & $\begin{array}{l}\text { Corruption Perceptions } \\
\text { range }\end{array}$ & $\begin{array}{l}\text { Transparency } \\
\text { International }\end{array}$ \\
\hline
\end{tabular}

\section{Methods}

We start our empirical investigation using a panel model. It is commonly recognized that panel data sets possess several advantages over cross-sectional or time series data sets. It gives the researchers a larger number of data points. Moreover panel data models are able to capture the

${ }^{1}$ Argentina, Australia, Brazil, Canada, China, France, Germany, India, Indonesia, Italy, Japan, South Korea, Mexico, Russia, Saudi Arabia, South Africa, Turkey, the United Kingdom, and the United States.

${ }^{2}$ The World Bank.How we Classify Countries. Available: http://data.worldbank.org/about/country-classifications. Last accessed 27th Aug 2013.

Income group: Economies are divided according to 2012 GNI per capita, calculated using theWorld Bank Atlas method. The groups are: low income, $\$ 1,035$ or less; lower middle income, $\$ 1,036$ - $\$ 4,085$; upper middle income, $\$ 4,086$ - $\$ 12,615$; and high income, $\$ 12,616$ or more.

To simplify the model, we combine the upper middle-income group and the lower middle-income group into middle-income group. 
individual heterogeneity (at the country level in this case) by introducing an individual specific effect term in the regression model, thus improving the estimation performance (Baltagi, 2008).

We prefer linear model to log-linear model in this study mainly because of its computational simplicity, the immediate interpretability of some of its coefficients and its temporal aggregability (Galeotti and Lanza, 2005). A linear model yields constant marginal effects and variable elasticities.

\section{ESTIMATION RESUlTS}

\section{A. Full Sample Regressions Results}

We estimate both two-way fixed effects and random effects models. We do choose the FE against the RE as our preferred model since the Hausman test suggests that the FE estimator remains consistent whereas the RE estimator does not and $\mathrm{u}_{\mathrm{i}}$ is correlated with at least one of the explanatory variables. Moreover, we decide to use the FE model with robust cluster (by country) standard errors, since that the default FE estimation overestimates the significance of every explanatory variable. The results are given in Table II below.

TABLE II. FULL SAMPLE REGRESSIONS RESUlTS

\begin{tabular}{|c|c|c|}
\hline \multirow{2}{*}{ Variables } & \multicolumn{2}{|c|}{ FE (clustered robust) } \\
\hline & Coefficients & $P$-value \\
\hline $11 \mathrm{gdp}$ & $\begin{array}{c}0.0006476 \\
(0.0002287)\end{array}$ & $0.011 * *$ \\
\hline 11ind & $\begin{array}{c}0.0645518 \\
(0.0215836)\end{array}$ & $0.008 * * *$ \\
\hline $11 \mathrm{cpi}$ & $\begin{array}{c}0.1959695 \\
(0.0512104)\end{array}$ & $0.001 * * *$ \\
\hline $\begin{array}{c}\text { y12 } \\
\text { (year 2006) }\end{array}$ & $\begin{array}{l}-0.4296932 \\
(0.2216308) \\
\end{array}$ & $0.068^{*}$ \\
\hline $\begin{array}{c}\text { y13 } \\
\text { (year 2007) }\end{array}$ & $\begin{array}{l}-0.5204807 \\
(0.2620952)\end{array}$ & $0.062^{*}$ \\
\hline $\begin{array}{c}\text { y14 } \\
\text { (year 2008) }\end{array}$ & $\begin{array}{l}-0.6757217 \\
(0.263647)\end{array}$ & $0.020 * *$ \\
\hline $\begin{array}{c}\text { y15 } \\
\text { (year 2009) }\end{array}$ & $\begin{array}{c}-1.148099 \\
(0.2851251) \\
\end{array}$ & $0.001 * * *$ \\
\hline $\begin{array}{c}\text { y16 } \\
\text { (year 2010) }\end{array}$ & $\begin{array}{c}-0.5939488 \\
(0.2666056) \\
\end{array}$ & $0.039 * *$ \\
\hline
\end{tabular}

According to results of the FE model with cluster robust standard error, the variables $11 \mathrm{gdp}$ which is one-year lag of GDP per capita is significant, while $\mathrm{GDP}^{2}$ and $\mathrm{GDP}^{3}$ (11gdp_2 and 11gdp_3) are not. This implies that the relationship between carbon dioxide emissions and income is monotonic, a \$1 (U.S. dollar based on PPP in 2005) increase in the GDP per capita leads to a 0.00065 tonnes $\mathrm{CO}_{2}$ per capita increase. The share of industrial value added in GDP (11ind) is significant, a rise of 1 percentage point leads to 0.065 tonnes $\mathrm{CO}_{2}$ per capita increase. Thus there is evidence that industry sectors do have negative impact on the environment. The Corruption Perceptions Index (11cpi) is also significant and has a positive impact with carbon emissions, if the value of the index rises by 0.1 which means less corruption within the country, the per capita $\mathrm{CO}_{2}$ emissions increase 0.02 tonnes. This is the opposite from our expectation, may be misleading. Since 2006, the time dummy variables are significant, and have negative signs. This may be because of steep increase of oil price since 2004, leading to countries switching to less energy consuming and less polluting activities, thus carbon emissions reduction occurred. However the trade variables are insignificant and not of the expected sign.

\section{B. Group Regressions Result}

Since developed and developing countries are in different stages of economic development and technological positions, We carry out our empirical investigation separately for the sample of high-income and middle-income countries, the results are given in Table III below.

TABLE III. GROUP REGRESSIONS RESULTS

\begin{tabular}{|c|c|c|c|c|}
\hline \multirow{2}{*}{ Variables } & \multicolumn{2}{|c|}{ Group 1-high income } & \multicolumn{2}{|c|}{ Group 2- middle income } \\
\hline & Coefficients & $P$-value & Coefficients & $P$-value \\
\hline $11 \mathrm{gdp}$ & $\begin{array}{c}0.0003476 \\
(0.0001355)\end{array}$ & $0.028 * *$ & $\begin{array}{c}0.0010287 \\
(0.0003008)\end{array}$ & $0.011 * *$ \\
\hline 11gdp_2 & $\begin{array}{c}3.82 \mathrm{e}-09 \\
(6.64 \mathrm{e}-09)\end{array}$ & 0.578 & $\begin{array}{l}-3.43 \mathrm{e}-08 \\
(5.20 \mathrm{e}-08)\end{array}$ & 0.531 \\
\hline $11 \mathrm{gdp} \_3$ & $\begin{array}{c}-1.57 \mathrm{e}-13 \\
(8.61 \mathrm{e}-14)\end{array}$ & $0.098^{*}$ & $\begin{array}{c}2.79 \mathrm{e}-13 \\
(2.37 \mathrm{e}-12)\end{array}$ & 0.910 \\
\hline $11 \mathrm{imp}$ & $\begin{array}{c}0.0590227 \\
(0.0466673)\end{array}$ & 0.235 & $\begin{array}{l}-0.0299136 \\
(0.0153931)\end{array}$ & $0.093 *$ \\
\hline $11 \mathrm{exp}$ & $\begin{array}{c}-0.0257898 \\
(0.0283152)\end{array}$ & 0.384 & $\begin{array}{l}0.0389148 \\
(0.010277)\end{array}$ & $0.007 * * *$ \\
\hline 11 ind & $\begin{array}{c}0.0923459 \\
(0.0431548)\end{array}$ & $0.058 *$ & $\begin{array}{c}0.0081588 \\
(0.0107452)\end{array}$ & 0.472 \\
\hline $\begin{array}{c}\text { y5 } \\
\text { (year 1999) }\end{array}$ & $\begin{array}{c}-0.0587317 \\
(0.1648566)\end{array}$ & 0.729 & $\begin{array}{l}-0.3251347 \\
(0.1287544)\end{array}$ & $0.040 * *$ \\
\hline $\begin{array}{c}\text { y7 } \\
\text { (year 2001) }\end{array}$ & $\begin{array}{l}-0.1222004 \\
(0.2110982)\end{array}$ & 0.575 & $\begin{array}{l}-0.4800874 \\
(0.1601721)\end{array}$ & $0.020 * *$ \\
\hline $\begin{array}{c}\mathrm{y} 8 \\
\text { (year 2002) }\end{array}$ & $\begin{array}{c}-0.1876857 \\
(0.2582874)\end{array}$ & 0.484 & $\begin{array}{c}-0.447215 \\
(0.1520608)\end{array}$ & $0.022 * *$ \\
\hline $\begin{array}{c}\text { y9 } \\
\text { (year 2003) }\end{array}$ & $\begin{array}{c}-0.0285478 \\
(0.2813519)\end{array}$ & 0.921 & $\begin{array}{l}-0.3567663 \\
(0.1319977)\end{array}$ & $0.031 * *$ \\
\hline $\begin{array}{c}\text { y10 } \\
\text { (year 2004) }\end{array}$ & $\begin{array}{c}-0.0965224 \\
(0.2875713)\end{array}$ & 0.744 & $\begin{array}{l}-0.2795446 \\
(0.1122587)\end{array}$ & $0.042 * *$ \\
\hline $\begin{array}{c}\text { y11 } \\
\text { (year 2005) }\end{array}$ & $\begin{array}{c}-0.3155204 \\
(0.3531528)\end{array}$ & 0.393 & $\begin{array}{c}-0.395826 \\
(0.1133775)\end{array}$ & $0.010 * * *$ \\
\hline $\begin{array}{c}\text { y12 } \\
\text { (year 2006) }\end{array}$ & $\begin{array}{c}-0.5302247 \\
(0.3468589)\end{array}$ & 0.157 & $\begin{array}{l}-0.4626621 \\
(0.1353334)\end{array}$ & $0.011 * *$ \\
\hline $\begin{array}{c}\text { y13 } \\
\text { (year 2007) }\end{array}$ & $\begin{array}{l}-0.6697851 \\
(0.4007711)\end{array}$ & 0.126 & $\begin{array}{l}-0.4808182 \\
(0.1631274)\end{array}$ & $0.021 * *$ \\
\hline $\begin{array}{c}\mathrm{y} 14 \\
\text { (year 2008) }\end{array}$ & $\begin{array}{l}-0.9172316 \\
(0.3707964)\end{array}$ & $0.033 * *$ & $\begin{array}{l}-0.5249261 \\
(0.1860199)\end{array}$ & $0.026 * *$ \\
\hline $\begin{array}{c}\text { y15 } \\
\text { (year 2009) }\end{array}$ & $\begin{array}{c}-1.527717 \\
(0.4064855)\end{array}$ & $0.004 * * *$ & $\begin{array}{l}-0.6869271 \\
(0.1961901)\end{array}$ & $0.010 * * *$ \\
\hline $\begin{array}{c}\text { y16 } \\
\text { (year 2010) }\end{array}$ & $\begin{array}{l}-0.7724349 \\
(0.4266004)\end{array}$ & $0.100 *$ & $\begin{array}{l}-0.5879647 \\
(0.2097346\end{array}$ & $0.026^{* *}$ \\
\hline constant & $\begin{array}{c}-1.71026 \\
(2.373365)\end{array}$ & 0.488 & $\begin{array}{c}-2.411785 \\
(0.6053359\end{array}$ & $0.005^{* * * *}$ \\
\hline
\end{tabular}

Compare to the full sample estimation, the results of group estimations are quite different, both in terms of magnitude and of statistical significance. 
For the high-income countries, GDP, GDP ${ }^{2}$ and $\mathrm{GDP}^{3}$ are jointly significant. However the signs are not as expected for $N$-shaped $\left(\left(\beta_{1}>0, \beta_{2}<0, \beta_{3}>0\right)\right.$, instead they are $\beta_{1}>0, \beta_{2}>0$, $\beta_{3}<0$. This suggests there is an inverted-U shape environmental Kuznets curve with one turning point in the real sector at \$36461(see Figure I ). Only United States has already passed the turning point, implies that as it further develops the carbon emissions decrease and environmental quality improves, by importing more pollution intensive good at the expense of environmental quality in other countries, or by switching away from coal and oil to cleaner fossil fuels and nuclear and hydroelectric power because the increasing demand for cleaner environment from residents. For the share of industrial value added in GDP, a rise of 1 percentage point leads to 0.092 tonnes $\mathrm{CO} 2$ per capitaincrease, but this is only significant at the $10 \%$ level. The period dummy variables are significant since year 2008, maybe because the high-income countries are less sensitive to the increasing of energy prices.

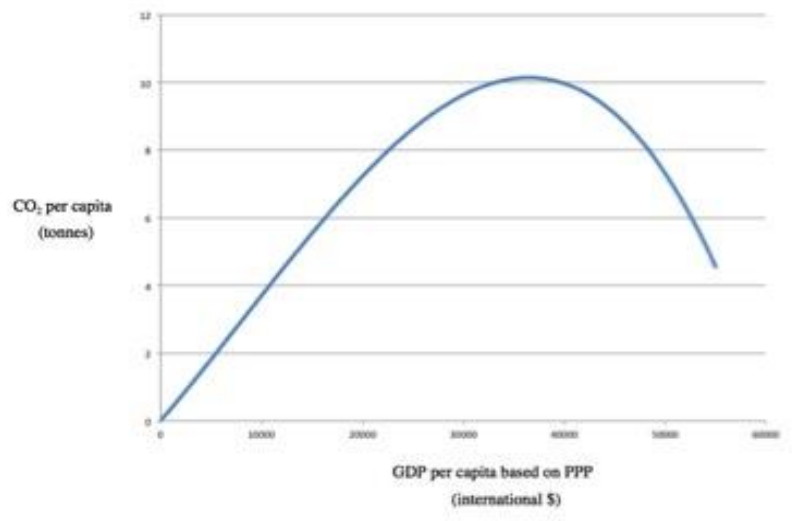

FIGURE I. EXAMPLE OF A ONE-COLUMN FIGURE CAPTION

For the middle-income countries, the relationship between economic growth and carbon emissions are monotonic as the full sample analysis, maybe because these developing countries are in the earlier stage that stilldeveloping economy at the expense of environment. Carbon emissions are increasing as the economies are growing. Different from the full sample and high-income countries cases, imports and exports are both significant. It provides evidence for the pollution haven hypothesis, $\mathrm{CO}_{2}$ emissions go up 0.039 tonnes as exports share of GDP grows up $1 \%$, and go down 0.030 tonnes as imports share of GDP increases $1 \%$. The time dummy variables are significant since 1999, except for 2000, maybe because of Kyoto Protocol (1997) has greater influence in developing countries than developed countries.

\section{CONCLUSIONS}

This study estimates the environmental Kuznets curve for the 19 countries from G20 group, and tries to examine the key determinants of carbon emissions. Due to the fact that other factors such as trade, industry sector value added and corruption perceptions index may also have impact on
$\mathrm{CO}_{2}$ emissions, we expand our estimation models by including these factors into the models as control variables.

The result shows that the Environmental Kuznets Curve may exist, however the turning point is really high, this goal is still many decades away. For the full sample and middleincome group, $\mathrm{CO}_{2}$ is monotonically increasing with economic growth, while for the high-income group, carbon emissions begin to decrease at a high turning point. For the middle-income countries, imports and exports are significant, provide some evidence for the Pollution Haven Hypothesis, $\mathrm{CO}_{2}$ emissions go up as exports grow and go down as imports increase. The industry sector does have a negative impact on the environment for both the full sample and the high-income group. As mass production and consumption grow, carbon emissions increase.

Therefore, the policy based on a "wait and grow" assumption is not adequate. Governments need to undertake policies as soon as possible to reduce levels of $\mathrm{CO}_{2}$ emissions. For individual countries, options for economic growth with a less increase in pollution include: (i) increasing the service industry share; (ii) importing pollution intensive goods; (iii) strengthen controls on air pollutions; and (iv) increasing technology innovations on energy efficiency. However, the first two solutions reduce carbon emissions domestically on the expense of other countries' environment. Only the last one is the real solution for controlling $\mathrm{CO}_{2}$ emissions worldwide. Future policies for climate change and pollution should explicitly focus on technological innovations.

\section{ACKNOWLEDGMENT}

This paper is funded by the planning project of Beijing Foreign Studies University (2011XG003).

\section{REFERENCES}

[1] Arrow, K., Bolin, B., Costanza, R., Dasgupta, P., Folke, C., Holling, C. S., Jansson, B., Levin, S., Maler, K., Perrings, C., Pimentel, D. (1995). Economic Growth, Carrying Capacity, and the Environment. Ecological Economics. 15, 91-95.

[2] Baltagi,B.H (2008) Econometric analysis of panel data, 4th Edition, Hoboken, NJ: John Wiley \& Sons, Inc.

[3] Galeotti, M., Lanza, A. (2005). Desperately seeking environmental Kuznets. Environmental Modelling \& Software. 20, 1379-1388.

[4] Galeotti, M., Lanza, A., Pauli, F. (2006). Reassessing the environmental Kuznets curve for $\mathrm{CO}_{2}$ emissions: A robustness exercise. Ecological Economics. 57, 152-163.

[5] He, J., Richard, P. (2010). Environmental Kuznets curve for $\mathrm{CO}_{2}$ in Canada. Ecological Economics. 69, 1083-1093.

[6] Iwata, H., Okada, K., Samreth, S. (2012). Empirical study on the determinants of $\mathrm{CO}_{2}$ emissions: evidence from OECD countries. Applied Economics. 44 (27), 3513-3519.

[7] Jayadevappa, R., Chhatre, S. (2000). International trade and environmental quality: a survey. Ecological Economics. 32 (2), 175194.

[8] Taylor, M. S. (2005). Unbundling the Pollution Haven Hypothesis. The B.E. Journal of Economic Analysis \& Policy. 2, 1-28

[9] Temurshoev, U. (2006). Pollution Haven Hypothesis or Factor Endowment Hypothesis: Theory and Empirical Examination for the US and China. CERGE-EI Working Papers wp292. The Center for Economic Research and Graduate Education - Economic Institute, Prague. 